\title{
MERARIK; ALTERNATIF MODEL PEMBELAJARAN BAHASA INDONESIA KESETARAAN PAKET C PROGRAM PENDIDIKAN VOKASI PARIWISATA
}

\author{
Syafruddin Muhdar \\ Program Studi Pendidikan Bahasa dan Sastra Indonesia \\ FKIP Universitas Muhammadiyah Mataram \\ rudybastrindo@gmail.com
}

\begin{abstract}
Abstrak
Model Pembelajara MERARIK merupakan salah satu alternatif pembelajaran yang mampu mengkombinasikan antara teori dan aplikasi sehingga siswa mampu merasakan pengalaman belajar yang menarik. Tujuan dari penelitian ini adalah mendeskripsikan Merarik; sebagai Alternatif Model Pembelajaran Bahasa Indonesia Program Kesetaraan Paket C Pendidikan Vokasi Pariwisata.

Hasil dari model pembelajaran merarik: Pembelajaran Student Center, Pembelajaran Lebih Bermakna, Pemberian Penghargaan, Budaya Membaca, Penanaman Karakter. Beberapa kelebihan yang dimiliki oleh model pembelajaran ini adalah sebagai berikut: a) Mudah diterpakan, b) Bisa diaplikasikan ke materi dan mata pelajaran yang lain, c) Meningkatkan antusiasme siswa terhadap pembelajaran yang dilaksanakan, d) Pengemasan pembelajaran yang dilakukan sedemikian rupa sehingga siswa merasa enjoy dan tidak terbebani seperti ketika pembelajaran dilakukan secara konvensional, e) Dapat menumbuhkan minat baca siswa sehingga dapat menanamkan budaya gemar membaca.
\end{abstract}

Kata Kunci: model, merarik, kesetaraan, pembelajaran bahasa Indonesia.

\section{PENDAHULUAN}

Dari berbagai potensi yang ada di NTB, maka tidak salah jika Nusa Tenggara Barat menjadi salah satu destinasi utama di Indonesia. Data kunjungan wisatawan, baik wisatawan mancanegara maupun domestik yang berkunjung ke Nusa Tenggara Barat pada tahun 2014 adalah sejumlah 1.629.122. meningkat $16,67 \%$ dibanding tahun sebelumnya yang hanya berjumlah 1.357.602. Bahkan, lebih menggembirakan lagi pada saat ini jumlah kunjungan wisatawan telah mencapai 2,2 juta orang dari target pencapaian tahun
2016 sebesar 3 juta orang (Data Pusat Statistik NTB).

Di tengah tuntutan yang semakin tinggi terhadap perlunya peningkatan kinerja sektor pariwisata agar dapat memenuhi pencapaian target-target ekonometrik, terasa bahwa pembenahan sumber daya manusia belum kuat disuarakan. Terdapat kesan yang cukup menonjol bahwa perhatian masih bertumpu pada aspek kuantitatif, yakni seberapa kesempatan kerja dan kunjungan wisata, sementara aspek kualitatif yang antara lain dilihat dari perubahan positif mutu sumber daya manusia cenderung diabaikan. Hal ini 
sebenarnya bertentangan dengan tujuan logika yang mendasari pembangunan pariwisata itu sendiri, bahwa target-target ekonomi tersebut hanya dapat dicapai jika persoalan sumber daya manusia lebih dulu ditangani.

Dalam pendidikan vokasi, proses interaksi siswa dengan tutor dan sumber belajar pada suatu lingkungan belajar disipakan untuk pekerjaan dan keahlian terapan tertentu. Oleh karena itu pembelajaran mengarah pada pendidikan terapan yang mendukung kompetensi lulusan sehingga setiap pembelajaran lebih bersifat pembimbingan.

Model Pembelajara MERARIK merupakan salah satu alternatif pembelajaran yang mampu mengkombinasikan antara teori dan aplikasi sehingga siswa mampu merasakan pengalaman belajar yang menarik. Melaui pembelajaran BI menggunakan model merarik, siswa dapat mengembangkan berbagai kecerdasan, karakter, dan kepribadian. Dengan penguasaan BI secara aktif, siswa lebih mengekspresikan kemampuan dirinya secara lugas, logis, dan sistematis. Bahkan siswa pun akan memahami gagasan orang lain sebagai pengalaman dalam pembelajaran $\mathrm{BI}$. Kemampuan inilah yang dapat mengembangkan kecerdasan, karakter, dan kepribadian melalui proses berpikir sinergis. Dengan pengembangan kemampuan ini, siswa diharapkan mampu bersaing di dunia industri tidak terkecuali Industri pariwisata di NTB.

Berdasarkan hal tersebut maka penulis tertarik mengangkat penelitian yang berjudul "Merarik ; Alternatif Model Pembelajaran Bahasa Indonesia Pendidikan Vokasi Pariwisata".

\section{PEMBAHASAN}

\section{Inovasi Pembelajaran}

MERARIK adalah sebuah model pembelajaran yang memungkinkan peserta didik mengerjakan kegiatan beragam untuk mengembangkan keterampilan, sikap, dan pemahamannya dengan penekanan belajar sambil bekerja.

MERARIK merupakan singkatan dari pembelajaran Membaca, Merangkai, dan Meringkas, merupakan sebuah model pembelajaran kontekstual yang melibatkan paling sedikit tiga prinsip utama dalam proses pembelajarannya. MERARIK juga merupakan pendekatan pembelajaran yang memungkinkan peserta didik melakukan kegiatan yang beragam untuk mengembangkan ketrampilan, sikap, dan pemahaman dengan penekanan kepada belajar sambil bekerja, sementara guru menggunakan berbagai sumber dan alat bantu belajar termasuk pemanfaatan media supaya pembelajaran lebih menarik, menyenangkan, dan efektif. Pengertian 
Model Pembelajaran MERARIK dapat dijabarkan sebagai berikut :

a. Pembelajaran Membaca

Hodgson dalam (Isah Cahyani dan Hodijah 2007: 98)Membaca adalah suatu proses yang dilakukan serta dipergunakan oleh pembaca untuk memperoleh pesan yang hendak disampaikan oleh penulis melalui media kata-kata/ bahasa tulis. Suatu proses yang menuntut agar kelompok kata yang merupakan suatu kesatuan akan terlihat dalam suatu pandangan sekilas, dan agar makna katakata secara individual akan dapat diketahui. Kalau hal ini tidak terpenuhi, maka pesan yang tersurat dan yang tersirat tidak akan tertangkap atau dipahami, dan proses membaca itu tidak terlaksana dengan baik. Hodgson.

Pendapat lain dikemukakan Klein (dalam Rahim,2008:3) bahwa membaca mencakup 1. Membaca merupakan suatu proses, 2. Membaca adalah strategi, 3. Membaca merupakan interaktif. Membaca merupakan siatu proses dimaksudkan informasi dari teks dan pengetahuan yang dimiliki oleh pembaca mempunyai peran yang utama dalam membentuk makna. Membaca juag merupakan suatu strategi. Pembaca yang efektif menggunakan berbagai strategi membaca yang sesuai dengan teks dan konteks dalam rangka mengontruks makna ketika membaca.
Membaca adalah interaktif, keterlibatan pembaca dengan teks tergatung pada konteks.

b. Pembelajaran Merangkai

Pembelajaran merangkai adalah pembelajaran secara berkelompok maupun individu dengan menemukan dan merangkai ide pokok paragraph dalam sebuah bacaan. Pembelajaran ini juga dapat digunakan untuk mencocokkkan kartu pertanyaan dan kartu jawaban yang telah disediakan sesuai dengan soal. Selain itu pula, pembelajaran merangkai adalah salah satu permainan bahasa, pada hakikatnya permainan bahasa merupakan suatu aktivitas untuk memperoleh keterampilan tertentu dengan cara menggembirakan.

Pembelajaran merangkai terdiri atas bermacam-macam bentuk yakni :

Merangkai kata, yakni sebuah permainan menyusun kata-kata dan huruf-huruf yang telah dikacaukan letaknya sehingga membentuk suatu kata tertentu yang bermakna misalnya : alpjera = pelajar, ktarsurt $=$ struktur

Merangkai kalimat : yakni sebuah permainan menyusun kalimat dari kata-kata acak. Bentuk kalimat hendaknya logis, bermakna, tepat, dan benar. Contohnya c. Merangkai wacana : yakni 
sebuah permainan menyusun wacana logis berdasarkan kalimatkalimat acak. Hasil susunan wacana hendaknya logis, bermakna.

Merangkai Ide Pokok Paragraf: Yakni kegiatan menemukan dan menyusun ide pokok aragraf sesuai dengan isi bacaan.

Berdasarkan uraian di atas, dapat disimpulkan bahwa pembelajaran Merangkai merupakan metode yang berbentuk permainan acak kata, kalimat, atau paragraf.

c. Pembelajaran Meringkas

Ringkasan adalah bentuk singkat atau ringkasan sebuah buku, bab, ataupun artikel yang masih mempwerlihatkan sosok dasar dari aslinya atau tidak meninggalkan urutan dasarnya dari buku yang diringkas.sedangkan kata precis berarti memangkas. Olivia (2009:30) menyatakan bahwa ringkasan adalah suatu cara yang efektif untuk menyajikan suatu karangan yang panjang dalam bentuk yang singkat.

Meringkas isi suatu wacana, merupakan salah satu kompetensi dasar yang harus dikuasai oleh seluruh siswa. Dalam pembelajaran meringkas isi wacana, siswa dituntut mampu menuliskan hal-hal penting dari informasi yang disajikan dalam suatu wacana. Penilaian dalam meringkas isi wacana, difokuskan pada ketepatan isi ringkasan dan ketepatan penulisan isi ringkasan.

Dengan memiliki kemampuan menulis ringkasan yang baik, maka siswa diharapkan dapat melihat dan menyelesaikan suatu masalah rumit dengan cara sederhana dan cepat, karena telah mengetahui gambaran umum tentang suatu wacana atau peristiwa, baik itu dalam bentuk tulisan maupun dalam masalah sehari-hari.

Setiap orang dalam membuat suatu ringkasan tentu mempunyai tujuannya masing-masing sesuai dengan kebutuhannya. Beberapa tokoh mengemukakan tujuan dari meringkas itu sendiri seperti yang dikemukakan oleh Gorys Keraf dalam Olivia (2009: 29) yaitu: Membuat ringkasan dapat berguna untuk mengembangkan ekspresi serta penghematan kata. Latihan membuat ringkasan, menurut dia, akan mempertajam daya kreasi dan konsentrasi si penulis ringkasan tersebut. Penulis ringkasan dapat memahami dan mengetahui dengan mudah isi karangan aslinya, baik dalam penyusunan karangan, cara penyampaian gagasannya dalam bahasa dan susunan yang baik, cara pemecahan suatu masalah, dan lain sebagainya.

Dari pernyataan di atas, dapat kita lihat bahwa meringkas memiliki manfaat yang sangat berguna untuk memahami dan 
mengetahui dengan mudah isi sebuah wacana, baik dalam penyusunan maupun dalam cara penyampaian gagasan.

\section{Prosedur Model Pembelajaran Merarik}

Pembelajaran MERARIK merupakan salah satu model pembelajaran pada mata pelajaran Bahasa Indonesia. Model pembelajaran MERARIK merupakan pembelajaran awal/permulaan pada model pembelajaran Membaca. Dalam model pembelajaran ini, pembelajarannya selalu diawali dengan kegiatan membaca. Antara lain membaca dalam hati, atau membaca lancar. Pilihan tergantung situasi pembelajaran seperti apa yang dikehendaki/diinginkan, dan relevansinya dengan tujuan pembelajaran. Merangkum sama dengan resume atau meringkas. Yang perlu dicatat dalam rangkuman adalah halhal yang dirasa cukup penting, materi pokok atau pokok pikiran utama.

Langkah-langkah yang ditempuh dalam penerapan model pembelajaran

MERARIK adalah sebagai berikut :

a) Tutor/ Guru menjelaskan tujuan pembelajaran/KD.

b) Tutor/ Guru memaparkan materi cara membuat rangkuman dengan benar.

c) Siswa dibagi dalam beberapa kelompok beranggotakan 3-4 siswa. d) Pembagian kelompok dilakukan dengan teknik merarik, yaitu tutor akan memilih $3 / 4$ siswa yang akan menjadi anggota inti kelompok tersebut. Pemilihan anggota inti didadarkan atas kemampuan dan kelebihan siswa tersebut.

e) Pemilihan anggota kelompok yang lain akan dilakukan oleh kelompok yang lain pula. Misalnya kelompok A akan memilihkan anggota untuk kelompok B, dan kelompok B akan memilihkan anggota untuk kelompok $\mathrm{C}$, begitu seterusnya.

f) Tutor/ Guru menyiapkan naskah/bacaan dengan tema cerita yang menarik sesuai dengan Kotak Bakat.

g) Tiap-tiap kelompok membaca naskah/wacana tersebut dengan cermat

h) Setelah membaca, siswa mencari dan merangkai ide pokok paragraf sesuai dengan urutannya.

i) Setelah menemukan ide pokok paragraf, baru kemudian memulai kegiatan meringkas/merangkum sesuai dengan bacaan yang diperoleh.

j) Masing-masing kelompok mempresentasikan hasil dari kegiatannya secara bergantian 
k) Demikian seterusnya sampai seluruh kelompok tampil.

1) Diakhir pembelajaran, guru akan memberikan tugas individu kepasa seluruh warga belajar dengan mengambil materi di Kotak Bakat.

m) Evaluasi,

n) Kesimpulan.

\section{Hasil Pembelajaran Merarik}

Pembelajaran menggunakan model MERARIK memiliki dampak/hasil sebagai berikut:

1. Pembelajaran Student Center

Selama proses pembelajaran mengunakan model pembelajaran merarik, pembelajaran berpusat pada peserta didik, baik pada saat berdiskusi, merangkum isi bacaan, membacakan rangkuman dan menanggapi penampilan kelompok yang menyampaikan hasil kelompoknya.

2. Pembelajaran Lebih Bermakna

Model pembelajaran Merarik mengajarkan siswa untuk bisa bekerjasama dan bertukar fikiran dengan anggota kelompok yang lain. Selain itu pula desain pembelajaran yang menuntut siswa untuk berfikir dan menulis menjadikan model pembelajaran ini menjadi lebih bermakna.

3. Pemberian Penghargaan

Setiap siswa/ kelompok yang tampil dan memberikan argumentasinya mendapatkan penghargaan berupa tepuk

tangan dan pujian. Hal ini mendorong siswa untuk dapat memaksimalkan kinerja kelompok maupun individu. Perlakukan ini dapat sebagai motivasi atau dorongan bahwa apa yang mereka sampaikan dan kerjakan mendapatkan apresiasi yang baik dari guru dan teman sebaya.

4. Budaya Membaca

Melalui kegiatan ini siswa diajarkan untuk gemar membaca, sehingga ilmu pengetahuan yang didapat tidak semata berasal dari tutor/guru, tetapi lebih dari pada itu buku-buku yang tersedia dapat menjadi tambahan pengetahuan yang tak ternilai harganya. Hal ini dapat berguna untuk kehidupan bermasyarakat dan pekerjaan.

\section{Penanaman Karakter}

Melalui pembelajaran Model Merarik, peserta didik ditanamkan nilai-nilai karakter. Hal ini terlihat dari proses pembelajaran yang mengajarkan tentang saling menghargai dan selalu bekerjasama dengan anggota kelompok yang lain.

\section{Keunggulan Model Pembelajaran}

\section{Merarik}

\begin{tabular}{lrr}
\multicolumn{2}{c}{ Keberhasilan penerapan } & model \\
pembelajaran yang dipilih & dalam \\
mengatasi permasalahan yang & muncul \\
disebabkan oleh & adanya \\
keunggulan/kelebihan dalam & model \\
pembelajaran ini. Beberapa kelebihan yang
\end{tabular}


dimiliki oleh model pembelajaran ini adalah sebagai berikut.

a) Mudah diterpakan

b) Bisa diaplikasikan ke materi dan mata pelajaran yang lain

c) Meningkatkan antusiasme siswa terhadap pembelajaran yang dilaksanakan

d) Pengemasan pembelajaran yang dilakukan sedemikian rupa sehingga siswa merasa enjoy dan tidak terbebani seperti ketika pembelajaran dilakukan secara konvensional.

e) Dapat menumbuhkan minat baca siswa sehingga dapat menanamkan budaya gemar membaca.

\section{Kelemahan Model Pembelajaran Merarik}

Pelaksanaan pembelajaran melalui penerapan model Merarik telah menciptakan suatu perubahan positif, baik pada proses maupun hasil belajar siswa. Namun, tidak dapat dipungkiri adanya kelemahan-kelamahan ketika proses pembelajaran berlangsung. Adapun kelemahan model pembelajaran merarik adalah sebagai berikut.

1. Ketika siswa melakukan kegiatan membaca dibutuhkan kondisi ruang belajar yang tenang agar siswa dapat berkonsentrasi dalam membaca bacaan.
2. Dalam pelaksanaan pembelajaran model Merarik siswa membutuhkan waktu yang cukup lama untuk membaca dan memahami isi bacaan. Sehingga diperlukan waktu yang banyak untuk sekali pertemuan.

3. Terdapat beberapa siswa yang memerlukan bimbingan untuk menemukan ide pokok paragraf. Sehingga tutor/ guru dituntut aktif memberikan bimbingan dan bantuan bagi peserta didik yang merasa kesulitan.

\section{PENUTUP Simpulan}

Berdasarkan hasil analisis dan pembahasan tentang penerapan Merarik sebagai alternative model pembelajaran pendidikan vokasi industri pariwisata di Lombok, maka dapat ditarik simpulan sebagai berikut.

a) Melalui model Pembelajaran Merarik, motivasi siswa untuk mengikuti proses pembelajaran menjadi lebih meningkat, sehingga siswa menjadi lebih aktif, berani tampil ke depan dan partisipatif dalam setiap tahapan kegiatan yang dilaksanakan.

b) Melalui penerapan model pembelajaran merarik, nilai karakter dan pengetahuan siswa 
menjadi meningkat. Hal ini

berdampak positif untuk peserta

didik ketika berbaur dengan

masyarakat dilingkungan social

maupun pada saat bekerja.

\section{Saran}

Adapun beberapa hal yang perlu diperhatikan berdasarkan temuan-temuan yang diperoleh dari pembelajaran model merarik untuk perbaikan pembelajaran pada waktu yang akan datang adalah sebagai berikut.

a) Memperbanyak referensi buku yang berkaitan dengan kurikulum yang diarahkan kepada siswa atau peserta didik sehingga ketika lulus, siswa memiliki kompetesi untuk bekerja.

b) Melakukan perbaikan di segala sisi agar mendapatkan model pembelajaan yang dinginkan.

\section{DAFTAR PUSTAKA}

Cahyani Isah, Hodijah. 2007. Kemampuan Berbahasa Indonesia di Sekolah Dasar. Bandung: UPI Press.

Farida Rahim. 2008. Pengajaran Membaca di Sekolah Dasar. Jakarta: Bumi Aksara

Olivia Femi. 2009. Teknik Meringkas

Efektif Dengan Rumus 4P. Jakarta:

Gramedia 